\title{
Kualitas Karkas Ayam Broiler yang Diberikan Pakan Supplemen Limbah Wortel
}

\section{Quality of Broiler Chicken Carcass Provided with Carrot Waste Supplementary Feed}

\section{G G Maradon ${ }^{*}$ dan R Noviadi $^{1}$}

\author{
${ }^{1}$ Politeknik Negeri Lampung \\ Jalan Soekarno Hatta No 10 Bandar Lampung, Indonesia \\ *E-mail : gusma@polinela.ac.id
}

\begin{abstract}
Carrot waste is carrots with criteria that are not suitable for human consumption. Carrot waste contains various vitamins and minerals. This study aims to evaluate the quality of broiler chicken carcass. The study used a completely randomized design (CRD) with 4 treatments and 6 replications. The treatments given included $R O=0 \%$ additional feed from carrot waste; $R 1=0.5 \%$ additional feed waste carrots; $R 2=1 \%$ additional feed from carrot waste; $R 3=1.5 \%$ additional feed from carrot waste. The data obtained were tested for normality and homogeneity before being analyzed using the Analysis of Variants. If there is a difference then proceed with Duncan's multiple distance test. The results showed that the best results were given additional feed of carrot waste at the level of $1 \%$ to increase carcass weight and carcass percentage, carcass color would increase along with the increase in the level of carrot waste addition.
\end{abstract}

Keywords: Broiler, carcass quality, carrot waste

Diterima: 30 September 2020, disetujui 2 Desember 2020

\section{PENDAHULUAN}

Daging broiler merupakan salah satu sumber protein hewani yang dikonsumsi oleh masyarakat Indonesia. Konsumsi daging ayam broiler secara bertahap menunjukkan adanya peningkatan dimana konsumsi daging ayam broiler pada tahun 2018 sebesar 5,579 kg/kapita/tahun menjadi 5,683 kg/kapita/tahun pada tahun 2019 (Ditjenpkh, 2020).

Peningkatan jumlah konsumsi ayam broiler akan meningkat seiring dengan jumlah permintaan terhadap daging ayam broiler. Konsumen akan melihat kualitas dari daging ayam broiler yang dibeli. Kualitas daging ayam salah satunya dinilai dengan warna dari karkas. Warna karkas yang diminati konsumen adalah warna kulit cerah dan daging berwarna pink cerah. Warna karkas dapat diperoleh salah satunya dengan memberikan pigmentasi pada ayam broiler. Senyawa jenis karotenoid dapat dijadikan sebagai pewarna alami.

Wortel merupakan salah satu jenis umbi yang memiliki kandungan betakaroten dan xantofil yang bisa dijadikan sebagai pigmentasi pada kulit karkas. Grading pada wortel dilakukan untuk memisahkan wortel layak konsumsi dan tidak layak konsumsi. Wortel dengan kualitas rendah akan menjadi limbah dan permasalahan dilingkungan. Salah satu upaya menanggulangi permasalahan tersebut adalah dengan memanfaatkan limbah wortel sebagai feed aditif. Penelitian ini bertujuan untuk menguji produk ekstrak limbah wortel terhadap kualitas karkas ayam broiler. 


\section{METODE PENELITIAN}

Penelitian ini menggunakan day of chick (DOC) mixed sex yang berasal dari Sanusi Taufik Poultry Shop

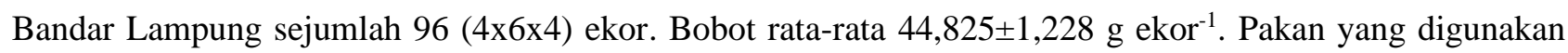
adalah pakan komersil broiler fase starter dan grower. Penelitian ini dilaksanakan di Kandang Jurusan Peternakan Politeknik Negeri Lampung.

\section{Ekstraksi Limbah Wortel}

Pembuatan ekstraksi limbah wortel menggunakan prosedur modifikasi Ikawati (2005) yaitu, limbah wortel dicuci, diparut, dan dibuat jus wortel. Jus wortel dicampur dengan pelarut (aceton : methanol = $7: 10$ ) dengan perbandingan jus wortel : pelarut $=1: 12$. Campuran bahan kemudian disaring menggunakan kertas saring. Hasil saringan dilakukan penguapan untuk memperoleh ekstraksi limbah wortel. Hasil ekstraksi dicampur dengan bahan inert sebelum dicampurkan dengan pakan.

\section{Metode Pemberian Ekstraksi Limbah Wortel}

Tepung ekstraksi limbah wortel yang sudah dicampurkan dengan bahan inert kemudian dicampurkan langsung dengan pakan yang ada. Pemberian pakan dan air minum dilakukan secara ad libitum. Pakan sisa ditimbang setiap hari.

\section{Rancangan Percobaan dan Analisis Data}

Penelitian dirancang menggunakan Rancangan Acak Lengkap (RAL) 4x6 dengan setiap petak ulangan terdiri atas 4 ekor broiler. Perlakuan yang diberikan yaitu:

$\mathrm{R} 0=0,0 \%$ pakan tambahan limbah wortel;

$\mathrm{R} 1=0,5 \%$ pakan tambahan limbah wortel;

$\mathrm{R} 2=1,0 \%$ pakan tambahan limbah wortel;

$\mathrm{R} 3=1,5 \%$ pakan tambahan limbah wortel

Data yang diperoleh dilakukan uji homogenitas dan normalitas, sebelum dilakukan analisis sidik ragam (ANARA). Jika ada perbedaan maka dilakukan uji lanjut menggunakan uji jarak berganda Duncan (Steel $e t$ al., 1997).

\section{Peubah yang diamati}

Peubah yang diamati antara lain

1. bobot hidup (g), diperoleh dengan cara mengukur bobot akhir broiler sebelum dipotong

2. bobot karkas (g), diperoleh dengan mengukur bobot hasil pemotongan dikurangi darah, bulu, dan organ visceral.

3. persentase karkas (\%), diperoleh dengan cara bobot karkas dibagi bobot hidup dikalikan $100 \%$.

4. warna karkas, diperoleh dengan cara membandingkan warna daging dengan kertas rosche.

\section{HASIL DAN PEMBAHASAN}

Hasil penelitian pada Tabel 1 menunjukkan bahwa pemberian ekstrak limbah wortel pada broiler memiliki pengaruh nyata $(\mathrm{P}<0.05)$ terhadap bobot hidup ayam broiler. Pemberian ekstrak limbah wortel pada broiler mampu meningkatkan bobot hidup ayam broiler sebesar 3-4\% yaitu 40-110 gram dibandingkan tanpa pemberian ekstrak limbah wortel. Hal ini disebabkan karena ekstrak limbah wortel memiliki beberapa nutrien yang terkandung didalam kandungannya. Pre-kursor vitamin seperti $\alpha$-karoten dan $\beta$-karoten banyak dimiliki oleh limbah wortel. Kedua pre-kursor tersebut akan mengaktifkan vitamin A. Vitamin A berperan 


\section{Maradon dan Noviadi : Kualitas Karkas Ayam Broiler yang Diberikan Pakan Supplemen Limbah Wortel/Peterpan 2 (2): 47-50}

dalam peningkatan efisiensi pakan dan pertumbuhan ayam broiler dengan meningkatkan timbunan jaringan urat daging di dalam broiler (Prasetyo et al., 2018 dan Olson, 1989).

Tabel 1. Rataan Kualitas Karkas Ayam Broiler yang Diberikan Ekstrak Limbah Wortel

\begin{tabular}{lrrrr}
\hline Peubah & \multicolumn{1}{c}{ R0 } & \multicolumn{1}{c}{ R1 } & \multicolumn{1}{c}{ R2 } & \multicolumn{1}{c}{ R3 } \\
\hline Bobot Hidup & $1.056,72^{\mathrm{a}}$ & $1.097,20^{\mathrm{b}}$ & $1.178,56^{\mathrm{c}}$ & $1.148,76^{\mathrm{d}}$ \\
Berat Karkas & $1.011,92^{\mathrm{a}}$ & $1.052,24^{\mathrm{b}}$ & $1.133,56^{\mathrm{c}}$ & $1.104,26^{\mathrm{d}}$ \\
Persentase berat karkas & $65,32^{\mathrm{a}}$ & $66,88^{\mathrm{b}}$ & $67,79^{\mathrm{b}}$ & $66,79^{\mathrm{b}}$ \\
Warna Karkas & $1,00^{\mathrm{a}}$ & $2,00^{\mathrm{b}}$ & $2,00^{\mathrm{b}}$ & $3,00^{\mathrm{c}}$ \\
\hline
\end{tabular}

Keterangan: Superscript yang berbeda antar perlakuan menunjukkan perbedaan yang nyata $(\mathrm{P}>0.05)$

$\mathrm{R} 0=$ feed supplement $0 \%$ ekstraksi limbah wort

el; R1=feed supplement $0,5 \%$ ekstraksi limbah wortel; R2 = feed supplement $1 \%$ ekstraksi limbah wortel; R3=feed supplement 1,5\% ekstraksi limbah wortel;

Hasil penelitian pada Tabel 1 menunjukkan bahwa pemberian ekstrak limbah wortel pada broiler memiliki pengaruh nyata $(\mathrm{P}<0.05)$ terhadap bobot karkas ayam broiler. Pemberian ekstrak limbah wortel pada broiler mampu meningkatkan bobot karkas dan persentase karkas sebesar 3-4\% yaitu sebesar 40—120 gram dibandingkan tanpa pemberian ekstrak limbah wortel. Peningkatan berat karkas akan searah dengan peningkatan berat hidup broiler (Olanrewaju et al., 2019).

Persentase karkas pada Tabel 1 menunjukkan hasil bahwa pemberian ekstrak limbah wortel pada broiler memiliki pengaruh nyata $(\mathrm{P}<0.05)$. Pemberian ekstrak limbah wortel pada broiler mampu meningkatkan persentase karkas sebesar 1,5—2,2 \%. Persentase karkas pada penelitian ini 65, 32-67,79\%, range ini masih berada dikisaran persentase karkas yang didapat Massolo et al. (2016) bahwa persentase karkas berkisar antara $66,37-73,29$.

Pigmentasi warna karkas pada penelitian ini menunjukkan hasil berpengaruh nyata $(\mathrm{P}<0.05)$. Pigmentasi warna karkas menghasilkan warna yang berbeda, hal ini disebabkan adanya peningkatan jumlah jumlah pigmen warna yang berasal dari ekstrak limbah wortel. Ekstrak limbah wortel memiliki senyawa aktif berupa betakaroten sebagai pigmen dari wortel. Betakaroten menyebabkan penguatan warna dari karkas broiler (Santoso, 2019).

\section{KESIMPULAN DAN SARAN}

Aplikasi penggunaan ekstrak limbah wortel dapat digunakan hingga taraf level 1,5\% untuk meningkatkan kualitas warna karkas ayam broiler. Penggunaan ekstrak limbah wortel terbaik diperoleh pada taraf $1 \%$ untuk meningkatkan bobot karkas dan bobot hidup.

Penggunaan produk ekstrak limbah wortel sebaiknya diuji cemaran secara mikrobiologis dan kimiawi dikarenakan berpotensi adanya cemaran yang mengurangi daya simpan .

\section{UCAPAN TERIMA KASIH}

Ucapan terimakasih sebesar-besarnya kepada pihak Politeknik Negeri Lampung yang membantu pendanaan melalui Dana Riset DIPA Politeknik Negeri Lampung.

\section{DAFTAR PUSTAKA}

Direktorat Jenderal Peternakan dan Kesehatan Hewan RI [Ditjenpkh]. 2020. Statistik Peternakan Dan Kesehatan Hewan 2020. Direktorat Jenderal Peternakan dan Kesehatan Hewan Kementerian Pertanian RI. Jakarta. 236 hal. Tersedia di https://ditjenpkh.pertanian.go.id.

Ikawati, R. 2005. Optimasi kondisi ekstraksi karotenoid wortel (Daucus carota L.) menggunakan response surface methodology (RSM). Jurnal Teknologi Pertanian 1(1): 14-22. 
Massolo, R., Mujnisa, A. dan Agustina, L. 2016. Persentase karkas dan lemak abdomial broiler yang diberi prebiotik inulin umbi bunga dahlia (Dahlia variabilis). Buletin Nutrisi dan Makanan ternak 12(2): 5058 .

Olanrewaju, H. A., Miller, W. W., Maslin, W. R., Collier, S. D., Purswell, J. L. dan Branton, S. L. 2019. Interactive effects of light-sources, photoperiod, and strains on growth performance, carcass characteristics, and health indices of broilers grown to heavy weights. Poultry Science 98(12): 62326240 .

Olson, J. A. 1989. Provitamin A Function of Carotenoids: The Conversion of $\beta$-Carotene into Vitamin A. The Journal of Nutrition 119(1): 105-108.

Prasetyo, T. J., Yunianto, V. D. dan Mahfudz, L. D. 2018. Pengaruh penggunaan tepung limbah wortel (Daucus carrota $\mathrm{L}$ ) dalam ransum terhadap efisisensi penggunaan protein dan kalsium ayam broiler. JITP 6(2): 102-109.

Santoso, U. 2019. Perbandingan suplementasi tepung kunyit dan campuran tepung kunyit plus ekstrak daun katuk fermentasi terhadap performa, mutu karkas dan komposisi gizi daging pada broiler. Jurnal Sain Peternakan Indonesia 14(1): 7-13.

Steel, R. G. D., Torrie, J. H. dan Dickey, D. A. 1997. Principles And Procedures Of Statistics: A Biometrical Approach. McGraw-Hill. New York. 666 hal. 